\title{
sciendo Evaluation of Tooth No. 2674 and ESCO Tooth 3D models
}

doi:10.2478/mape-2019-0034

Date of submission to the Editor: 07/2018

Date of acceptance by the Editor: 08/2018

MAPE 2019, volume 2, issue 1, pp. 345-355

\author{
Vlastimil Moni* \\ Petr Klouda \\ Tomáš Miletič \\ Brown Coal Research Institute j. s. c., Most, Czech Republic \\ František Helebrant \\ VŠB-Technical University of Ostrava, Czech Republic \\ Luboš Donát \\ SEVEN Group, Most, Czech Republic \\ Jan Blata \\ VŠB-Technical University of Ostrava, Czech Republic \\ Michal Řehoř \\ Brown Coal Research Institute j. s. c., Most, Czech Republic
}

\section{INTRODUCTION}

The bucket wheel of the excavator and geometry of cutting bodies are very important part of the mining machine because of direct interaction with mined rock (Helebrant, 2004; Helebrant et al., 2007). The shape and geometry of bucket cutting edge, geometry of tooth and material of cutting edge and tooth are very important for the efficiency of mining operations (Bris, 2010). We expect the enlargement of the lifetime period of excavators cutting bodies as a result of the solving of the project No TH03020368, TAČR, programme EPSILON, titled "The optimisation of the shape and material of ground and mining machines research". The main target of this research is discovering of optimum tooth shape and geometry for different mining conditions (Fries et al., 2010). The main research method were strength analyses of 3D models of tooth used in the Czech Republic. The article briefly summarises the comparison of the most frequent tooth No2673 and ESCO Super V39VYH. We used the "limit state method" according to ČSN 73 0031, the calculation contents of following stages (Gondek et al., 2000):

a. realisation of geometrical models of tooth No. 2673 and ESCO Super V39VYH

b. determination of embedding - models boundary conditions

c. determination of different loading conditions and its combination

d. calculation of internal forces

e. supervision of tolerability and acceptability

The comparison of the Most Basin situation with the important European coal localities is shown in the chapter No 8.

\footnotetext{
`moni@vuhu.cz
} 


\section{CALCULATION MODEL GEOMETRY}

We used the proportion and the shape of the calculations of the models created in the programme Autodesk Inventor v12 (Hradil, et al., 2018). We created the finite element net type TETRA10. The nominal size is $9,7 \mathrm{~mm}$ with local soften in contact areas tooth - knife (No of tooth 2673) and the nominal size 13,42 $\mathrm{mm}$ with local soften in contact areas adaptor - crown (bit) - spring (ESCO tooth) (Klouda, 2019).

The frontal angle position of the bucket: The angle of the connecting line tooth blade point - wheel rotation middle and the vertical is $90^{\circ}$ (see Figures $1 \mathrm{a}, 1 \mathrm{~b}$ ).

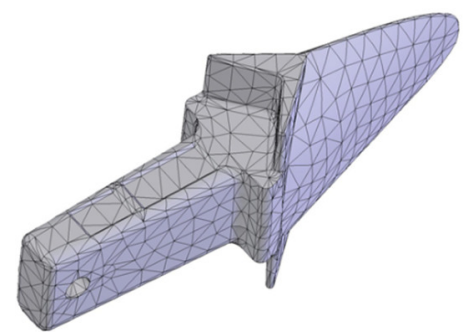

Fig. 1a Tooth model No 2673 with finite element net

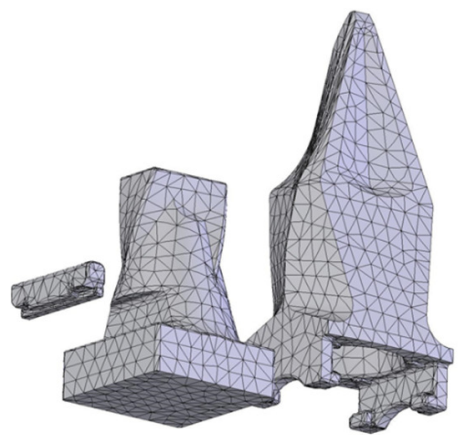

Fig. 1b Tooth model ESCO with finite element net (spring - adaptor - crown)

\section{CONTACT AREAS SITUATION}

It is possible to see discovered fixed contact areas of the tooth ESCO Super V39VYH -green lines (see Figures 2-4).

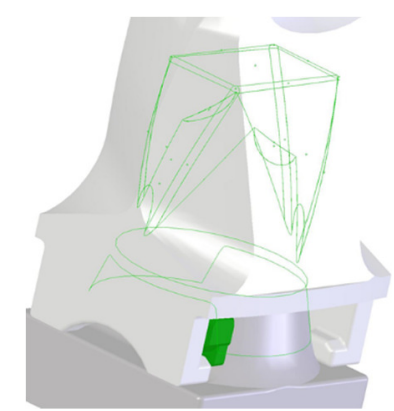

Fig. 2 Contact areas crown (bit) - adaptor ESCO Super V39VYH

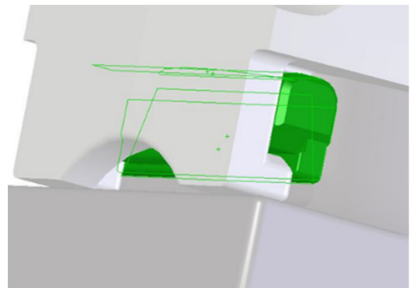

Fig. 3 Contact areas crown (bit) - spring - adaptor ESCO Super V39VYH 


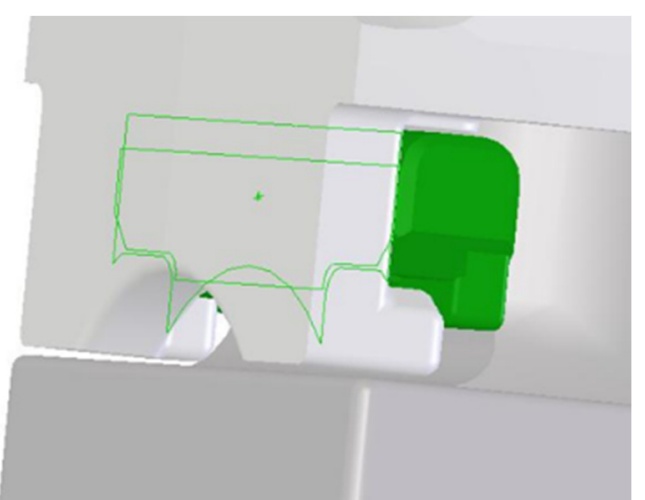

Fig. 4 Contact areas crown (bit) - spring ESCO Super V39VYH

\section{LOADING OF TOOTH}

The tooth loading depends on the bucket loading in agreement with ČSN 737008 (CSN, 1992). It was used VPN steel (about $850 \mathrm{MPa}$ ). The loading consists of permanent loading (own weight) and accidental loading (Moni et al., 2011). The resulting loading is the combination of different types of loading. The summary of loading combinations follows.

Permanent loading:

Sa) own weight of tooth

Accidental loading:

$\mathrm{Na}$ ) cutting force

$\mathrm{Nb}$ ) tooth material centrifugal force

$\mathrm{Nc}$ ) rock material in the bucket

$\mathrm{Nd)}$ centrifugal force of the rock material in the bucket

$\mathrm{Ne}$ ) lateral impact of the wheel

$\mathrm{Nf}$ ) supporting of the wheel

\section{Own weight of tooth}

Dependability coefficient of loading is $\gamma_{G}=1.1$. The loading is generated automatically by the programme for gravitational acceleration $\mathrm{g}=9.81 \mathrm{~ms}^{-2}$. The parameters are only the own weight of the tooth and the part of knife. The own weight of the tooth No 2673 is $G_{z}=118 \mathrm{~N}$ and the own weight of the tooth $E S C O G_{z}=98.875+85.739+$ $2.786=187.4 \mathrm{~N}$ (crown (bit) - adaptor - spring).

\section{Accidental loading}

Dependability coefficient of loading $\gamma_{Q R}=2.2$ was decreased to the value 1.6 because of adjustment of safety equipment. Maximum cutting force in the wheel is $F_{\max }=740$ $\mathrm{kN}$ in the case of the tooth No 2673, maximum cutting force in the wheel is $F_{\max }=896$ $\mathrm{kN}$ in the case of the tooth ESCO.

Directing of tooth in the wheel normal plane is possible to see in the next Figures 5 and 6 (Fries et al., 2010; Moni \& Klouda, 2008). 

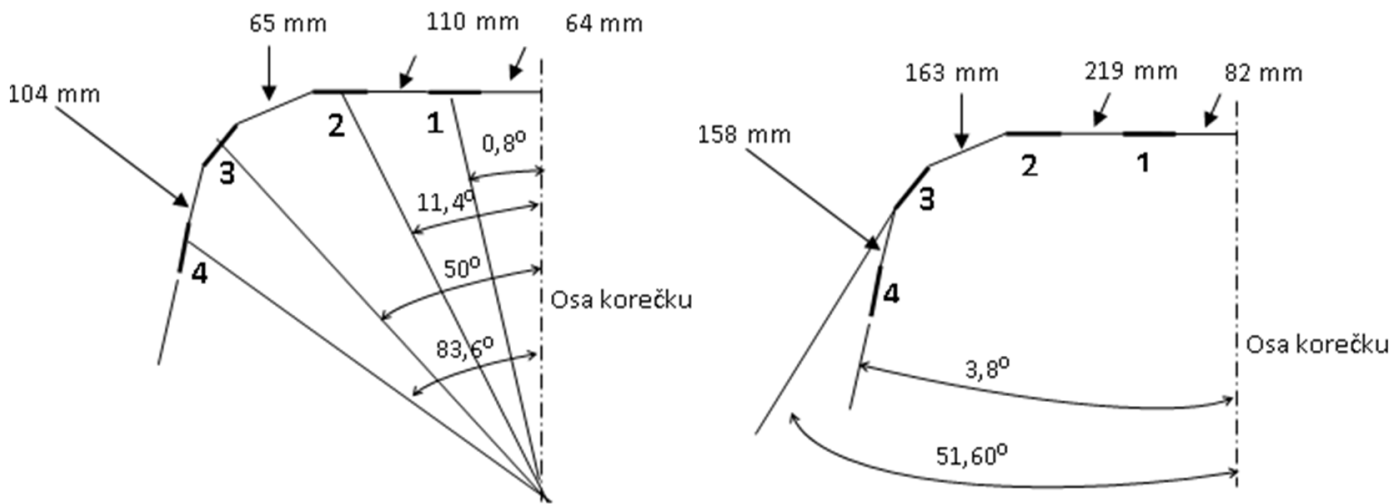

Fig. 5 Directing of the tooth No 2673 and ESCO in the wheel

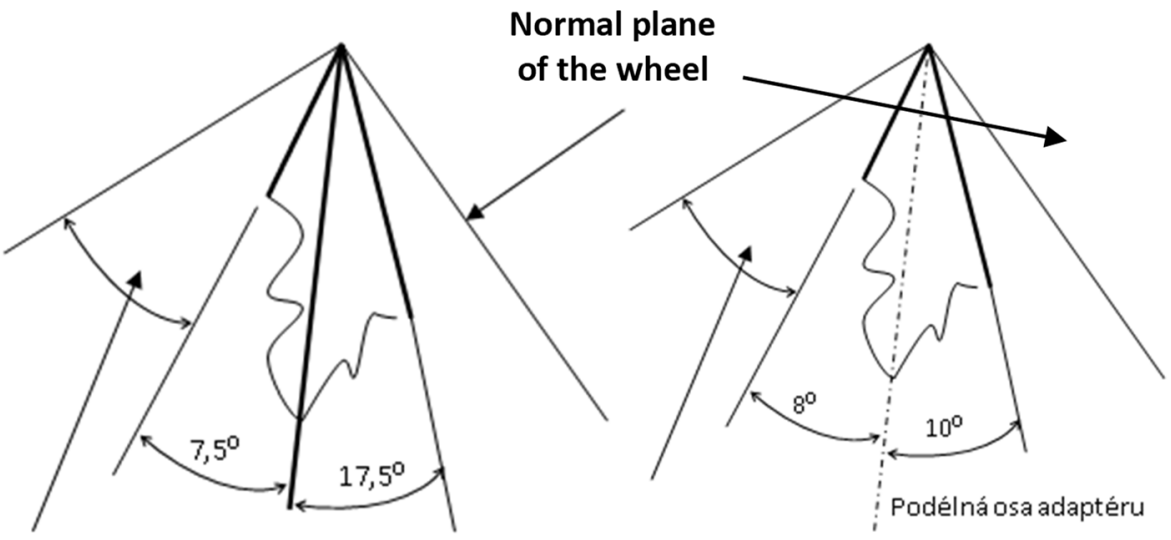

Fig. 6 Tooth blade with range angle - tooth No 2673 and tooth ESCO

\section{CALCULATION RESULTS}

The calculation was realised by linear statics for all loading situations $P, M M$ and $U$ (Fries et al., 2010; Moni, et al., 2014). These situations are:

- P-Operation - bench mining

$$
\text { - Operation - starting }
$$

- MM - Lateral impact

- Supporting of cutting body

- U - Fatigue 6 ) - bench mining

- Fatigue 6 - starting

We discovered maximum loading in the case of situation $P$ „operation - bench mining".

Maximum efficient stress [MPa] of model elements for calculated combinations are shown in next Tables 1-3. Exceptional (maximum) values are shown in brackets).

Table 1

Efficient stress [MPa] - tooth model ESCO

\begin{tabular}{|c|c|cc|}
\hline group & bench mining & fatigue- bench mining & supporting \\
\hline Crown (bit) & $1100 \div 1200(\geq 1600)$ & $800 \div 900(1600)$ & 1200 \\
\hline Adaptor & $900 \div 1000(\geq 1600)$ & $720 \div 800(1600)$ & $770 \div 800$ \\
\hline Spring & $167(357)$ & $165(254)$ & $80(290)$ \\
\hline
\end{tabular}


Table 2

Efficient stress [MPa] - tooth model 2673

\begin{tabular}{|c|c|c|c|}
\hline group & bench mining & fatigue- bench mining & supporting \\
\hline Blade & 440 & 336 & $>=1500$ \\
\hline Shank & 813 & 379 & 1500 \\
\hline Sector & 1258 & 591 & 1464 lokálně \\
\hline
\end{tabular}

Table 3

Shearing stress [MPa] - tooth model 2673

\begin{tabular}{|c|c|c|c|}
\hline group & bench mining & fatigue- bench mining & supporting \\
\hline Shank & -304 & 134 & 756 \\
\hline
\end{tabular}

The examples of efficient stress distribution in the tooth models ESCO and No 2673 (Moni \& Helebrant, 2011; Fries et al., 2013) during operation „fatigue - bench mining“ are shown in next Figure 7.
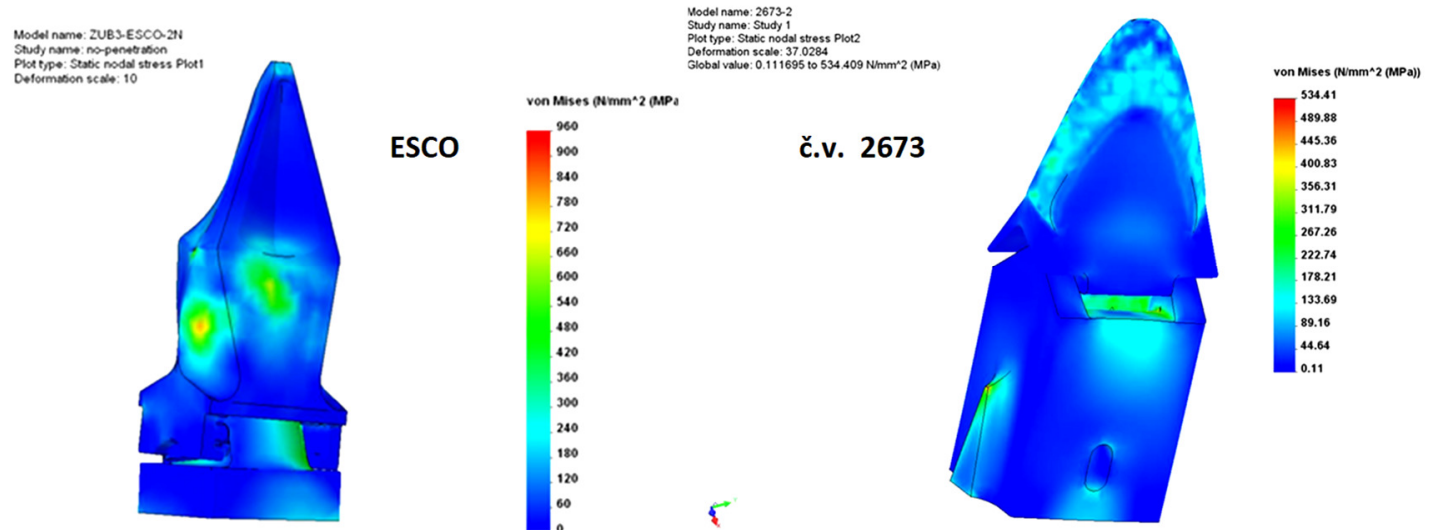

Fig. 7 Distribution of efficient stress in tooth models ESCO and No 2673

The example of efficient and shearing stress in the tooth model in the case of wheel supporting is shown in next Figures 8-9.

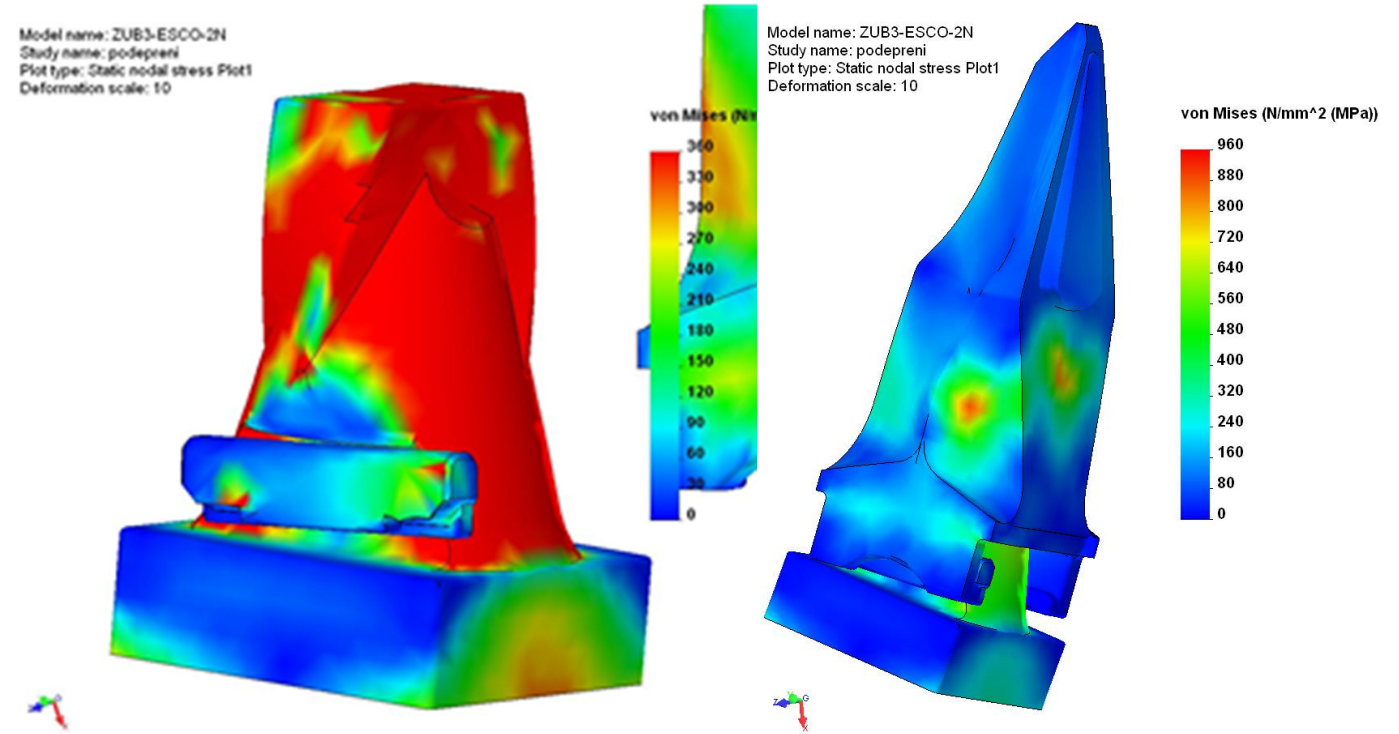

Fig. 8 Distribution of efficient stress in tooth models ESCO in the case of supporting of the wheel 

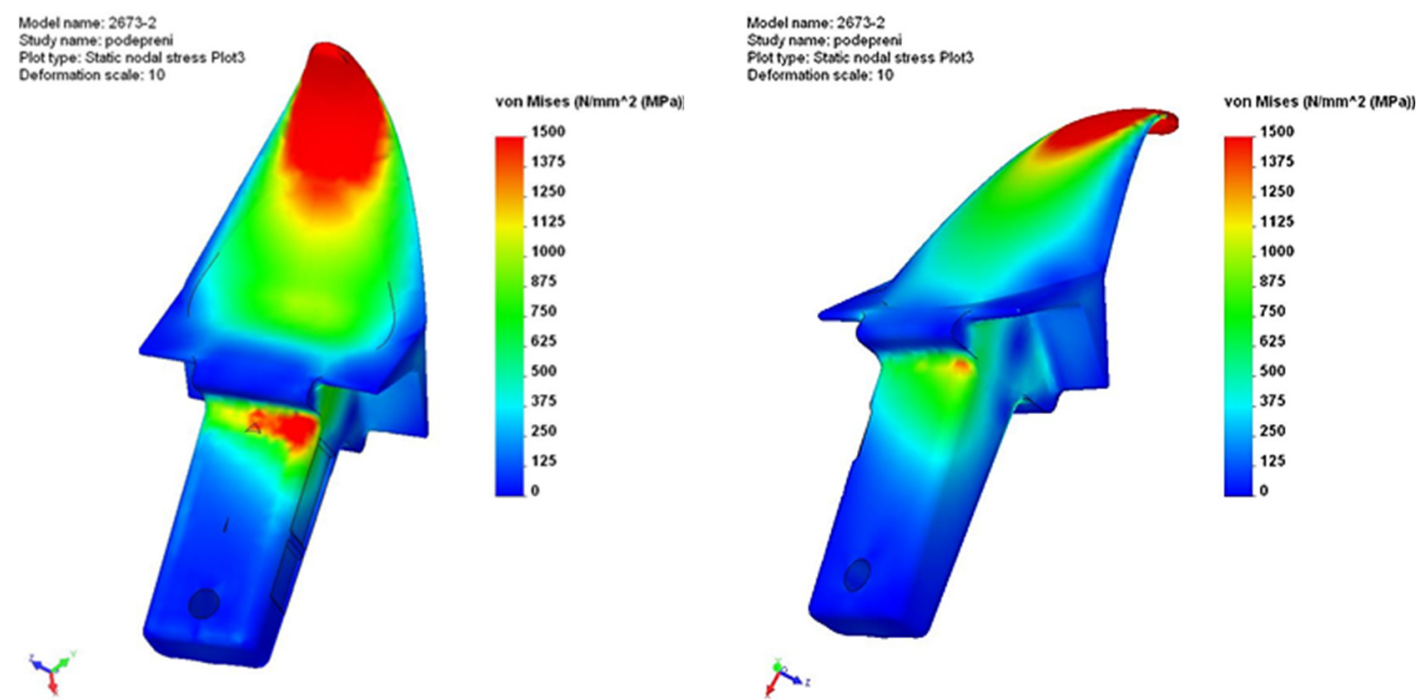

Fig. 9 Distribution of efficient and shearing stress in tooth model No 2673 in the case of supporting of the wheel

Calculated values of tooth model deformations [mm] for calculated loading combinations are shown in next Tables 4 and 5.

Table 4

Deformation [mm] of the ESCO tooth model

\begin{tabular}{|c|c|c|c|}
\hline group & bench mining & fatigue- bench mining & supporting \\
\hline Crown (bit) & 2.2 & 1.8 & 3.67 \\
\hline Adaptor & 0.96 & 0.7 & 0.96 \\
\hline Spring & 0.10 & 0.07 & 0.16 \\
\hline
\end{tabular}

Table 5

Deformation [mm] of the tooth No 2673 model

\begin{tabular}{|c|ccc|}
\hline group & bench mining & fatigue- bench mining & supporting \\
\hline Blade-top & 1.25 & 1.10 & 10.00 \\
\hline Blade-base & 0.33 & 0.28 & 0.83 \\
\hline
\end{tabular}

The examples of tooth deformations shapes in situation „fatigue - bench mining“ are shown in next Figures 10, 11.

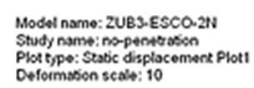

Plot t,pe: Sestic asplacomert Plot

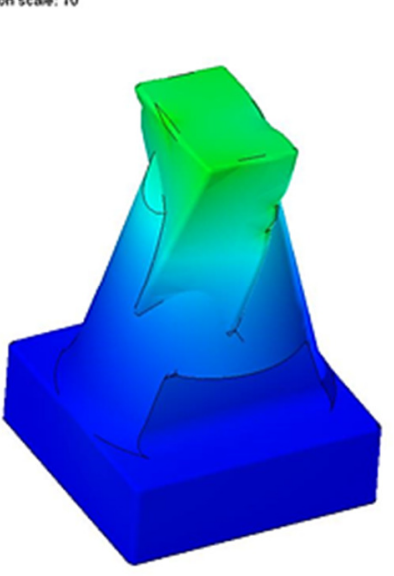

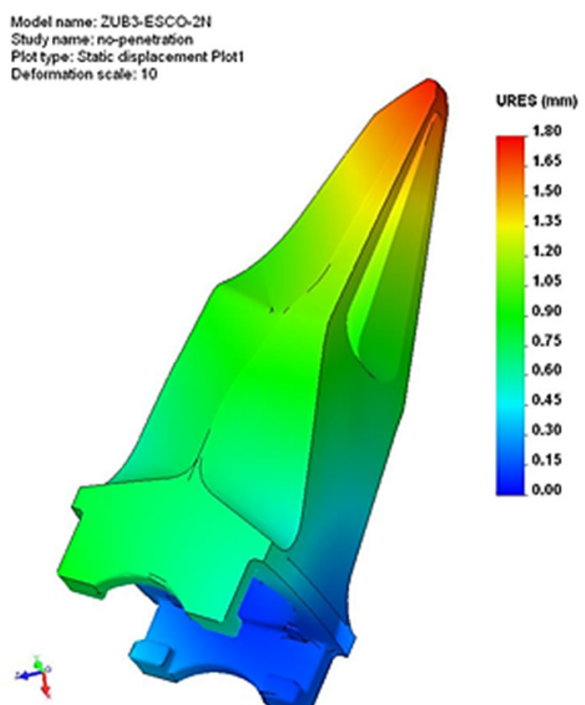

Hodol name: ZUBS. ESCO.2

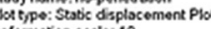

URES (mm)

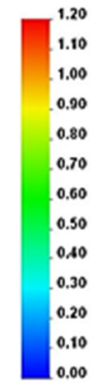

m

$$
\begin{aligned}
& 1.05 \\
& 0.90 \\
& 0.75 \\
& 0.60 \\
& 0.45 \\
& 0.30 \\
& 0.15 \\
& 0.00
\end{aligned}
$$$$
\begin{aligned}
& 1.65 \\
& 1.50
\end{aligned}
$$

Fig. 10 ESCO tooth model deformation in situation „fatigue - bench mining“ 


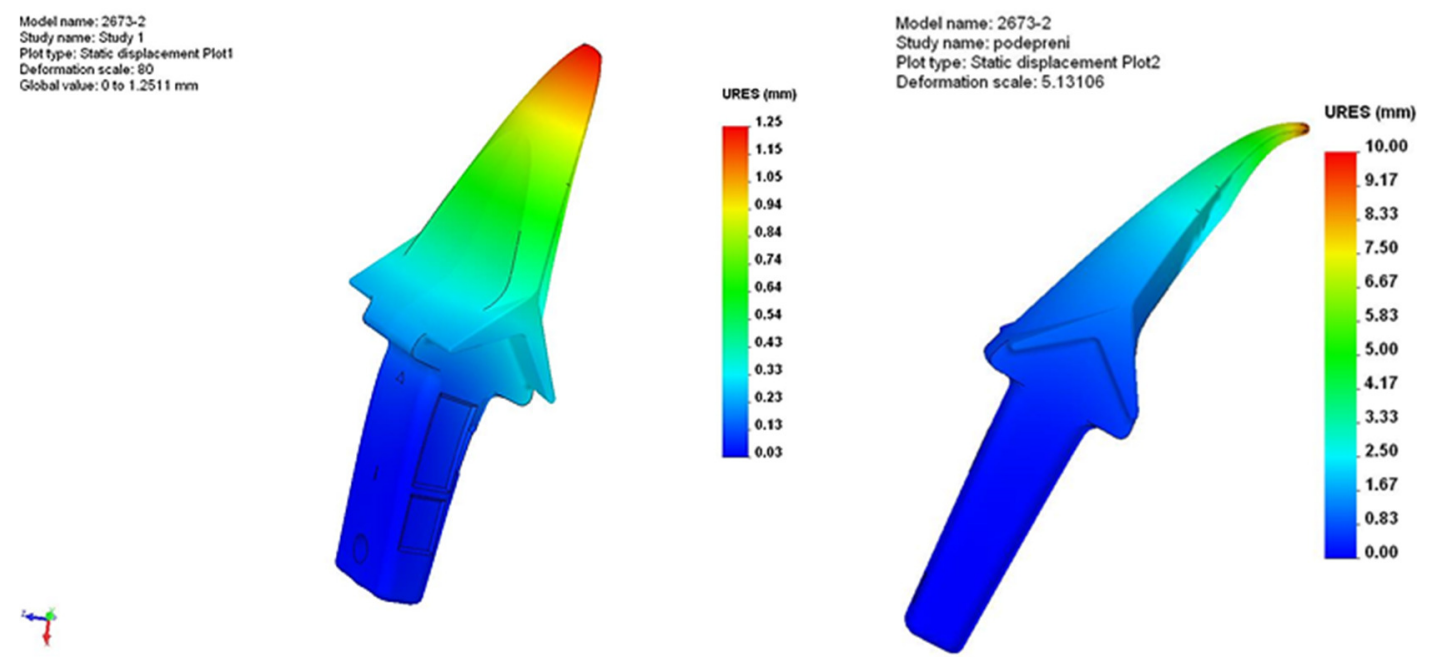

Fig. 11 Tooth No 2673 model deformation in situations „fatigue - bench mining“ and "wheel support"

\section{ACCEPTABILITY SUPERVISION}

The target of acceptability supervision is the verification of required values of strength and shape stability according to ČSN 27 7008. It is possible to obtain values of efficient stress in model construction according to theory HMH (von Mises) (Moni et al., 2013). It is the reason of possibility of direct evaluation of FEM analysis results (Klouda, 2009). Next formula is identical for crown, spring and adaptor, but values of $\sigma_{\text {ef }}$ are different.

For crown (bit), spring and adaptor of ESCO tooth and for tooth No 2673:

$\sigma_{\text {ef }} \leq \mathrm{f}_{\mathrm{y}} / \mathrm{y}_{\mathrm{MO}}=950 / 1.15=826 \mathrm{MPa}$

$$
\sigma_{e f}=\sqrt{\left\{\frac{1}{2}\left[\left(\sigma_{x}-\sigma_{y}\right)^{2}+\left(\sigma_{x}-\sigma_{z}\right)^{2}+\left(\sigma_{y}-\sigma_{z}\right)^{2}\right]+3\left(\tau_{x y}^{2}+\tau_{x z}^{2}+\tau_{y z}^{2}\right)\right\}}
$$

where:

$\sigma_{x,} \sigma_{y}, \sigma_{z},-$ normal stress

$\tau_{x,} \tau_{y}, \tau_{z}-$ shear stress

\section{RESULTS OF THE RESEARCH}

Results of ESCO tooth model in situation „operation“ and „fatigue“ Crown (bit)

The largest loading of the crown (bit) construction is running during bench mining. According the results the value of efficient stress $\sigma_{\text {ef }}[\mathrm{MPa}]$ is $1200 \mathrm{MPa}$ in adaptor hole, exceptionally $6200 \mathrm{MPa}$ in contact areas with adaptor and about $780 \mathrm{MPa}$ on the crown surface. The value of efficient stress in adaptor hole exceeds the limit (826 $\mathrm{MPa}$ ) over $45 \%$ and elastic limit over $26 \%$. The efficient stress values are under the limit value $826 \mathrm{MPa}$ with exception of described places. It is possible to expect plastic deformations in areas with efficient stress values above elastic limit. It is confirmed by deformation calculations.

\section{Adaptor}

The largest loading of the adaptor is running on the contact areas with the crown It is "Hertz pressure". The value of the contact stress is about 900-1000 MPa, exceptionally $4670 \mathrm{MPa}$. The values of efficient stress exceed the limit value $826 \mathrm{MPa}$ 
over $21 \%$ and elastic limit over $5 \%$. The efficient stress values are under the limit value $826 \mathrm{MPa}$ with exception of contact areas. It is possible to expect plastic deformations in areas with efficient stress values above elastic limit. It is confirmed by deformation calculations.

\section{Spring}

The value of a stress $167 \mathrm{MPa}$ is under limit value. The value of stress $357 \mathrm{MPa}$ was observed in the edge of the spring (problematic shape) in very small area. The value of efficient stress in adaptor hole exceeds the limit (250 MPa) over $43 \%$ and elastic limit over $19 \%$. It is possible to expect plastic deformations in this small area.

The tooth is convenient from point of view of comprehensive strength, but it is possible to expect permanent plastic deformations in contact areas the crown - adaptor. Four areas with stress values above are potential source of fissures.

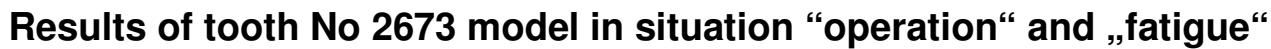

The largest loading of the knife construction is running during bench mining. The efficient stress $\sigma_{\text {ef }}[\mathrm{MPa}$ ] reaches the value $813 \mathrm{MPa}$ in changeover of Shang - blade and $440 \mathrm{MPa}$ in the top of frontal area of tooth blade according the results.

\section{The efficient stress $\sigma_{\text {ef }}[\mathrm{MPa}$ ] values do not exceed the limit value $826 \mathrm{MPa}$.}

The stress value $147 \mathrm{MPa}$ was observed in changeover of tooth - the pivot hole (Hertz pressure). It is common part of bucket construction with no problems. The limit value of contact stress is $1500 \mathrm{MPa}$. The tooth is convenient from this point of view.

\section{Applicability supervision}

The target of applicability supervision is the verification of the influence of the toot shape deformation to the usability of the tooth according to the paragraph No 7.3.1 of ČSN 277008.

The deformation requirement is very important for usability of the bucket:

The deformed part of the bucket must not be in contact with machinery groups in the surroundings of the wheel - i.e. deformation in the direction of wheel axis and in radial direction must not exceed the value $30 \mathrm{~mm}$. So the maximum possible tooth deformation value is $20 \mathrm{~mm}$ in the case of maximum possible bucket deformation value $10 \mathrm{~mm}$ (Gondek, 2007; Rehor et al., 2017).

- Maximum total deformation of the EXCO tooth observed "during operations“ was $2.2 \mathrm{~mm}$. It was reached during combination of loading „operation - bench mining“. The maximum total deformation was reached during loading situation „supporting of wheel". It was $3.7 \mathrm{~mm}$. The ESCO tooth is applicable from this point of view.

- Maximum total deformation of the tooth No 2673 observed „during operations" was $1.25 \mathrm{~mm}$. The tooth No 2673 is applicable from this point of view. It was reached during combination of loading „operation - bench mining“.

\section{DISCUSSION}

It was necessary to compare the Most Basin overburden rocks with the situation of the most important European coal basins was the part of presented research. It was evaluated the situation of the Belchatow area (Poland), the Lužice Basin (Germany and Poland), the Rhine Basin (Germany) and the Ptolemais and Megalopolis Basins 
(Greece) (Vossen, 2006, Poltegol, 2018).

The specific property of the Most Basin is very high content of clay and claystone in the overburden cuts of mining localities. The parameters of these rocks are different because to different content of siderite. The main overburden rock of majority of evaluated European coal basins is sand, in the case of Greece basins it is calcite too. The hard rocks of the Most Basin are siderite and quartzite, in next localities it is quartzite, calcite, crystalline boulders (Belchatow) and siderite (Poltegol, 2018).

These differences are very important for the evaluation of the overburden rocks abrasiveness and the impact to the optimum excavator construction. It is the reason of the necessity of the research aimed to the Most Basin overburden rocks parameters.

\section{CONCLUSION}

We realised calculation of loading and deformation of the steel construction of tooth No 2673 and ESCO tooth according to methodology of limit situations and ČSN 27 7008 during strength analysis of these tooth. The calculation was realised for provided 3D tooth model.

Border conditions were defined according to provided design of situation of the tooth in the bucket (tooth No 2673) and situation of the toot adaptor (ESCO tooth).

According the strength analysis, observed vales of the efficient stress off different parts of the tooth No 2673 construction and different parts of ESCO tooth (crown, adaptor, spring) reach the limit boundary of material strength (in the case of maximum digging force). These values exceptionally exceed this limit boundary in the case of ESCO tooth.

The ESCO tooth and tooth No 2673 are applicable from the point of view of the strength, but it is possible to expect permanent deformations in the case contact areas crown - adaptor (ESCO tooth). These four areas are the potential source of fissures. The producer of ESCO tooth recommends the changing of the adaptor after ten changes of crowns according to the results of this research.

The tooth constructions are applicable from point of view deformations according to functional analysis. According to all results of the strength analysis of provided 3D tooth models No 2673 and ESCO, the designed construction is acceptable from point of view of the strength for the mining of rock materials with the value of cutting force under180 $\mathrm{kNm}^{-1}$.

\section{ACKNOWLEDGEMENT}

The paper was realized with the support of the programme EPSILON of the Czech Republic Technology Agency TAČR, project No. TH03020368, titled "The optimisation of the shape and material of ground and mining machines research".

\section{REFEENCES}

ČSN 277013 91992) Kolesové rýpadla a nakladače, květen.

Briš R.: (2010), Výzkum závislostí pro energetickou náročnost, opotřebení a oteplení v kontextu s geometrií břitu a geologickými podmínkami při dobývacím procesu kolesových rýpadel, Technická zpráva, Kunčice pod Ondřejníkem, 49 s.

Gondek, H., Jurman J., Helebrant F.: (2000), Analýza teorie rozpojování hornin kolesovými rýpadly a objektivní náhled na ČSN 2707013, Centrum špičkových technologií pro hnědouhelné hornictví - subprojekt B, VŠB-TU Ostrava, 46 s., 64 přil. 
Helebrant F.: (2004), Konstrukce velkostrojů a jejich spolehlivost - II. provozní spolehlivost. I. vydání, Montanex, a.s. Ostrava, 89 s., ISBN 80-7225-149-X

Helebrant F., Jurman J., Fries J.: (2007), Kolesová rypadla a provozní spolehlivost. VŠB-TU Ostrava, 189 s., ISBN 978-80-248-1669-2

Fries, J., Jurman, J., Helebrant, F., Klouda, P., Moni, V.: (20110), Thermal Measurement of Conveyor Trucks and other Structural Points on Bucket Wheel Excavator SchRs 1320. In XVI. Medzinárodná konferencia Výzkum, výroba a použitie ocelových lán, dopravníkov a t'ažných zariadení; The International Journal TRANSPORT \& LOGISTICS, 7. Mimoriadne číslo časopisu, Košice, CD s. 168-172, ISSN 1451-107X.

Fries, J., Helebrant, F., Jurman, J, Klouda, P., Moni. V.: (2010), Capacity measuring on bucket wheel excavator k 2000. In 3rd International Symposium Energy Mining ER 2010, Banja Junakovič, Serbia, s. 441-445, ISBN 978-86-7352-215-9

Moni V., Klouda P.: (2008), Aplikace výsledků bezkontaktního měření teplot v hornické praxi. In Technická diagnostika Z1, ročník XVII, 27. mezinárodní vědecká konference DIAGO, s. 24-32, ISSN 1210-311X.

Klouda P.: (2019), Posouzení 3D modelu zubu ESCO Super V39VYH pro použití na rýpadle typové řady KU800.Technická zpráva VÚHU, Most, $30 \mathrm{~s}$.

Hradil D., Kotous J., Vomáčka P., Gregor T.: (2018), Vývoj zubů rypadel se zlepšenými vlastnostmi. COMTES FHT a.s.

Fries, J., Helebrant, F., Jurman, J., Klouda, P., Moni,V: (2010), Torsional moment measurement on bucket wheel shaft of giant machina. In 3rd International Symposium Energy Mining ER 2010, Banja Junakovič, Serbia, s. 436-440, ISBN 978-86-7352-2159

Moni, V., Helebrant, F.: (2011), Temperature Picture of a Bucket tooth and its Service Life. In Management Systems in Production Engineering, pp. 12-18, ISSN 2083-5280

Gondek, H.: (2007), Teoretický rozbor rozpojování hornin s ohledem na dosud existující teorie rozpojování a pevnostní chování a aspekty vzájemného působení hornin na dobývací orgán, Opava.

Moni, V., Helebrant, F., Chytka, L.: (2011), Influence of wheel bucket tooth thermal image on its life-time. In International Multidisciplinary Scientific GeoConference SGEM 2011, Conference Centre Flamengo Grand Albena, Bulharsko, s. 899-906, ISSN 1314-2704.

Řehoř M., Moni V., Novák V., Kraus V., Schmidt P.: (2017), Results of long term testing of geological situation and excavator SCHRS 1550-4X30/K109 parameters during the relocation to the position with the worse mining conditions in the Libous mine (the Most Basin), Scientific Geoconference SGEM 2016, Albena, 6-7, s.765-772, ISSN 1314-2704

Moni V., Řehoř M., Miletič T., Tauber J.: (2018), Research of the new materials and these materials adjustment for cutting bodies of excavators, Scientific Geoconference SGEM 2018, Albena, 6-7, s. 647-654, ISSN 1314-2704

Moni, V., Schmidt, P., Zíma R.: (2013), Complex long time measurements carried out on lignite heap in 2012. In International Multidisciplinary Scientific GeoConference SGEM 2013, Conference Centre Flamengo Grand Albena, Bulharsko, s. 333-340 -Volume I, ISSN $1314-2704$

Klouda P.: (2019), Výzkum vlivu tvaru a geometrie britu rozpojovacích orgánů kolesových rýpadel pomocí nových metod na energetickou náročnost a životnost. Grantový úkol č. 105/07/1031. Technická zpráva VúHU, Most, 19 s., AZL-102/09

Fries, J., Jurman, J., Helebrant, F., Moni, V. (2013), Thermal measurement of conveyor trucks and other structural points on bucket wheel excavator SchRs 1320.Kvalita, technologie, diagnostika v technických systémech; zborník vedeckých prác, SPU v Nitre, Technická fakulta, Nitra, s. 200-204, ISBN 978-80-552-1023-0

Moni V., Graman J., Donát L., Škaloud T., Klouda P., Helebrant F.: (2014). Optimisation possibilities of Operational Duty of Bucket Teeth of Wheel Excavator. In International Multidisciplinary Scientific GeoConference SGEM 2014, Conference Centre Flamengo Grand Albena, Bulharsko, ISSN 1314-2704.

Vossen P.: (2006), Continuous mining World of mining journal, Volume 58, p. 364-365, ISSN 1613-2408, 6.

Poltegol Instytut, (2018), Team of authors: Bucket wheel excavators operating under difficult mining conditions including unmineable inclusions and geological structures with excessive mining resistance BEWEXMIN project final report, Wroclaw, Poland. 
Abstract. The expense of restoring of excavators cutting bodies is increasing these days in the Most Basin area, primarily the replacement of tooth because of abrasion expense. The main reason is the complicated geological situation of overburden rocks, first of all the occurrence of sands and hard structures in the overburden cuts rocks in the deep horizons of open pit mines. Description of the first part of the strength analysis and applicability of 3D models of the tooth serial number 2673 and the tooth ESCO Super V39VYH with application of finite element method (FEM) is the main topic of this article. This research is the stage of the project based on optimisation of the shape and primarily the material used during manufacturing of the mining and ground machines cutting bodies in concrete mining conditions. The research is going on with application of new knowledge in the field of material engineering, metallurgy, cryogenic and nanotechnology. The main target is the increasing of mining process efficiency and the mining machines key node lifetime. Research of the excavator tooth parameters described in this article is very important part of the research.

Keywords: 3D model, tooth, bucket, cutting bodies, mining machine 